This is the Accepted Version of a forthcoming article that will be published by Emerald in Research in Political Economy, Vol. 31, 2016: http://www.emeraldinsight.com/series/rpec

Accepted Version downloaded from SOAS research Online: http://eprints.soas.ac.uk/22608/

\title{
Navigating the Aftermath of Crisis and Risk in Mexico and Turkey
}

Thomas Marois

School of African and Oriental Studies, University of London

Thornhaugh Street, Russell Square, London WC1H 0XG

tm47@soas.ac.uk

Hepzibah Muñoz-Martínez

Department of History and Politics, University of New Brunswick Saint John

100 Tucker Park Road, PO Box 5050, Saint John, New Brunswick, Canada E2L 4L5

hmartine@unb.ca 
NAVIGATING THE AFTERMATH OF CRISIS AND RISK IN MEXICO AND TURKEY

\begin{abstract}
This article aims to expose the economic and political relations of power disguised in the concept of financial risk as institutionalized in post-crisis economic policies and practices. We do so by examining, from a historical materialist approach, the actors and social struggles implicated in the aftermath of crisis in Mexico and Turkey. We argue that Mexican and Turkish state authorities have targeted workers so that they may disproportionately bear the costs of financial uncertainty and recurrent crises as workers, taxpayers, and debtors in the aftermath of the 2008-09 crisis. We emphasize, though, that there are important institutional mediations and case study specificities. Mexico's reforms that target labour as one of the main bearers of financial risk have been locked into legislation and constitutional changes. Turkey's policies have been implemented in a more ad hoc manner. In contemporary capitalism, we see risk as not confined to national borders but as also flowing through the world market. We further argue that the World Bank Report 2014 Risk and Opportunity: Managing Risk for Development emerges out of and reflects such real world responses to crisis that have been predominantly shaped by advocates of neoliberalism, to the benefit of capital. As an expression internal to global capitalism, the World Bank Report functions to legitimise the exploitative content of contemporary financial risk management policy prescriptions. Democratized financial alternatives that privilege the needs of workers and the poor are required.
\end{abstract}

KEYWORDS: Mexico, Turkey, neoliberalism, financial risk, crisis, economic policy 


\section{Introduction}

In the aftermath of the 2008-09 global financial crisis state authorities around the globe have undertaken new rounds of neoliberalization. These have included hardcore neoliberal projects like new privatizations, liberalization processes, the narrowing influence of democratic practices over economic reforms, and more restrictive labour reforms (Peck and Brenner 2012; Pradella and Marois 2015). Neoliberalization has also, and increasingly so, been about intensified financial liberalization, despite crisis, and associated processes of financial risk management. The latter is exemplified by the World Development Report 2014, Risk and Opportunity: Managing Risk for Development (World Bank 2013) and the focus topic of this special issue on Risk Management in Neoliberal Capitalism. Indeed, in the aftermath of the 2008-09 crisis financial risk has become a powerful buzzword meant to shape the contemporary political and economic practices of financial institutions and nation-states alike. Risk in this discourse is often associated with economic and political uncertainty, the probabilities of economic return and loss, or decision-making processes related to avoid financial losses (Holzer and Milo 2005: 225). Yet the concept of risk, as conventionally understood and practically employed, renders invisible the exploitative social relations needed to generate profits from capital accumulation and the class actors that differentially gain and lose in these processes.

For this reason, we aim to expose the economic and political relations of power disguised in the concept of financial risk as institutionalized in post-crisis economic policies and practices. We do so by examining, from a historical materialist approach, the actors and social struggles implicated in the aftermath of crisis in Mexico and Turkey. Consistent with the post-1980s trajectory of neoliberal reform, we argue that Mexican and Turkish state authorities in the aftermath of crisis have targeted the processes of labour as an important anchor of economic and financial stability. State authorities have targeted workers as agents so that they may disproportionately bear the costs of financial uncertainty and recurrent crises as workers, taxpayers, and debtors. We emphasize, though, that there are important institutional mediations and case study specificities. Mexico's reforms that target labour as one of the main bearers of financial risk have been locked into legislation and constitutional changes. Turkey's policies have been implemented in a more ad hoc manner. Despite such differences, forms of labour repression are consistent with the different state authorities' and foreign and domestic capitalists' attempts to manage the risky contradictions of finance-led capital accumulation in both countries. In contemporary capitalism, however, we see risk as not confined to national borders but as also flowing through the world market. We further argue that the World Development Report 2014 emerges out of and reflects such real world responses to crisis that have been predominantly shaped by advocates of neoliberalism, to the benefit of capital. As an expression internal to global capitalism, the Report functions to legitimise the exploitative content of contemporary financial risk management policy prescriptions.

The argument is developed as follows. First, we frame our critical approach to the study of risk. Second, we compare how state authorities have instituted labour as an anchor of post-crisis restructuring in Mexico and Turkey. This core section is broken into three interrelated discussions: economic decision-making and class power; 
restructuring, labour, and financial expropriation; and state policy and financialization. Third, we locate the World Development Report 2014 and its approach to financial risk management in the aftermath of crisis. This is followed by brief conclusion.

\section{Framing an Historical Materialist Approach to Financial Risk}

A historical materialist approach allows us to understand how risk is the expression of the calculation imperatives embedded in capital accumulation, where the processes of social labour embedded in the production of commodities (either material or immaterial) remain hidden. This calculation allows for the homogenous measuring of difference to calculate exposure to contingency, particularly the departure from the rate of capitalist return expressed as profit or loss (Bryan, Rafferty and Jefferis 2015; Martin 2015; Johnson 2013). This capitalist compulsion for calculation further disguises the processes of domination behind the notion of financial risk. An understanding of risk as the development of contradictions in capital accumulation offers insights into the social relations of conflict and domination behind risk, including how gains and losses are transferred to different social actors. Capital accumulation refers to the process of circulating value taking different material forms (finance, money, production activities and commodities) through various moments (production, circulation, realization) (Harvey 2010). Contradictory relations in capital accumulation are understood in a dialectical manner, where the opposing forces of both capital and labour are central to sustaining accumulation (Bryan 1995: 4). As a result, these contradictions do not disappear but rather are moved around and displaced (Harvey 2014: 4).

Labour is central to both these contradictions, which becomes a commodity in the process of capital accumulation (Marx 1975: 282-284). This involves the pre-existence of a dispossessed population that has nothing else but their labour power to sell in order to subsist while producing a surplus above what the worker needs for its subsistence (Harvey 2014: 63-64). Likewise, labour involves consumption and, more generally, social reproduction. As Marx argues, the labour process is not only implicated in production but also in consumption (Marx 1973: 90, 414). This is also part of the process of social reproduction where consumption, unpaid labour and social processes at home and in the community reproduce workers and their labour power (Cleaver 2000: 70). From this perspective, labour in the process of capital accumulation is not only considered in the moment of production, but also involves social processes outside of it including dispossession and social reproduction. For that reason, the unemployed and dispossessed are part of the labour process. This allows us to understand labour in capital accumulation beyond the traditional factory floor. It also allows us to examine the role of workers in Mexico and Turkey in the accumulation process as commodified labour power as well as debtors. This is central to an analysis of policy mechanisms that transfer the costs of the intensification of the contradictions in Mexico's and Turkey's capital accumulation onto labour in the context of financialization.

Financialization can be understood as the expansion of finance into all aspects of social life and as a historical transformation in capital accumulation, particularly in the ways in which different individuals, workers, capital, and the state are involved in those moments of capital connect to finance (Lapavitsas 2013). Costas Lapavitsas (2011) highlights that these changes are linked to the new capacity of corporations to obtain financial resources in international open markets, the shift in banking from traditional lending and savings activities towards the management of assets in open financial markets and the provision of financial services to workers, and the transformation of workers' income into a source of financial profit through consumption-based debt (Lapavitsas 2009). The latter represents a new form of accumulation through dispossession involving the removal of present and future means of subsistence from workers (Harvey 2005). In this way, finance permeates every act of production, 
consumption and social reproduction transforming it into potential financial assets that generate profit (Marazzi 2011: 107). Susanne Soederberg argues the importance of exploring the social power of money and its credit form under capitalism as fictitious capital and money-form revenue within financial processes (2014: 33-35). Otherwise, the concept of financialization can fetishize the realm of exchange and money without considering the power relations in production and exchange implicated in capital accumulation in its connection to money and credit (Soederberg, 2014: 21-22).

This fetishization of financialization is reflected in the World Development Report. On the one hand, the Report promotes financial inclusion and the deepening of access to market financial broadly in society. On the other hand, the Report dedicates significant analysis to the required state regulatory and supervisory institutions required to support an enhanced role for finance in development.

The processes of financialization are closely linked to neoliberalism as the former involves the restructuring and internationalization of the state to enable cross-border flows and to ensure an adequate and supportive financial apparatus (Marois 2012). Neoliberal policies carried out by state authorities since the late 1970 s have aimed at the intensification of market discipline, reducing the collective power of organized labour, and the commodification of all realms of social life through austerity policies, reregulation, privatization, and downward pressure on wages (Saad-Filho and Johnston 2005). The further commodification of labour has set the conditions for corporate welfare, monetarist and debtfarist neoliberal state policies in both Mexico and Turkey (Soederberg 2014: 47-60). As such, relations of economic and political power mediated and influenced politically and institutionally domestic policy experimentation within the confines of global neoliberal frameworks and the world market (See: Peck, 2004; Brenner et al. 2010). Within this perspective, the contemporary state is an institutional materiality grounded on capitalist social relations of production and social reproduction wherein different networks of power and resistance intersect politically to organize consent or dissent around particular strategies of accumulation (Poulantzas 1974; Jessop 1999).

The interconnections between neoliberal transformation, financialization and corporate welfare since the 1990s are evident in Mexico and Turkey as state policies protected powerful capitalist interests through capital account liberalization and bank privatization (Marois 2012; Soederberg 2014: 56). With capital account liberalization in 1989, the Turkish and the Mexican economies became further integrated into the world market, making the convertibility of their currencies and exchangeability of assets and production more uncertain as international financial transactions began to take place at different exchange rates and interest rates. Subsequent neoliberal reforms, including bank privatizations, led to the deepening of financialization in both countries. In both Mexico and Turkey the large firms and holding groups began concentrating more wealth in and increasing their involvement with financial activities (Garrido 2005, 100; Cizre-Sakallıoglu and Yeldan 2000, 487). As a result, large capital groups extended ownership and control over larger portions of their economies and increased their participation in international financial markets throughout the 1990s in Mexico and early 2000s in Turkey (UNCTAD 2011).

State authorities in Mexico and Turkey sought to mediate the contradictions developed by financialization in the 1990s within a transitioning monetarist neoliberal policy framework by focusing on reserve accumulation, austerity and low wages to preserve the value of their currencies and profitability and maintain low inflation, particularly after the Mexican peso crisis of 1995 and Turkey's 2001 financial crisis. Reserve accumulation remained central to the strength of the currency because it operates as an insurance against capital flight. Low inflation targets also helped to guarantee the 
worthiness of assets based on stagnant wages. Austerity helped to ensure the repayment of interest and principal on public debt, transfers of money to foreign reserves and decreases in the circulation of money in the economy to guarantee low inflation. Low wages then became a way to compensate for an appreciated currency in order to maintain the competitiveness of exports (Muñoz Martínez and Marois 2014). While this diminished internal aggregate demand, the potential negative effects of this outcome were compensated by sustained demand in international consumer markets until 2009 (UNCTAD 2013).

Monetarism and corporate welfarism led to the contraction of public provisioning, denigration of the public sphere and services, and neoliberal attacks on workers' rights have forced labour to become more reliant on debt in order to meet subsistence needs (Harvey 2005; McDonald and Ruiters 2012; Roberts 2013). This was the starting point of the expansion of debtfarism in both Mexico and Turkey. Through debtfare neoliberal policies consumer credit replaced wages and social programmes, allowing the unemployed and underemployed to socially reproduced while subjecting to market discipline (Soederberg 2014: 60-61)

Yet, diversity and conflict exist within the capitalist class as they are differentially connected to financialization, commodity production and distribution. Diversity and conflict also exists among workers in the context of increasing competition for jobs and wages, as the reserve army of labourers multiplies, and in relation to their access to debt and financial assets (Harvey, 1999: 69; Cleaver, 2000: 114). Both vary according to country specificity. Also, class interests do not directly control the political and economic conditions in which governments and state authorities formulate and implement policy (De Brunhoff 1978). Nevertheless powerful political and economic actors constantly seek to refashion neoliberal policies according to existing domestic institutional landscapes and in their own interests (Brenner et al. 2010: 202-3). The World Development Report 2014 openly acknowledges the significance of country fit and specificity, yet most recommendations to financial risk management disproportionately favour financial interests over those of workers by either passing the costs of risk onto labour or by advocating labour's deeper subordination to market financial mechanisms, hence financialization.

\section{Anchoring Labour to Financial Risk Management in the Aftermath of Crisis}

When mortgage foreclosures increased in the US, mainly subprime, mortgage lenders, investment banks and hedge funds collapsed in 2007 . The financial crisis spread over global credit markets as returns on risk increased rapidly and liquidity diminished. The initial impact of the crisis on Europe and the US in 2008 had serious consequences on Mexico and Turkey, as these countries rely economically for export markets and investment. The consequences were capital flight, reduced domestic production and currency depreciation (Muñoz-Martínez and Marois 2014). In their immediate response to the 2008-09 global crisis, Mexican and Turkish state authorities implemented the neoliberal and finance-led policies of reserve accumulation, inflation targeting, fiscal austerity and low wages developed since the mid-1990s (Muñoz-Martínez and Marois 2014). Yet three significant differences emerged amidst the 2008-09 crisis. First, the balanced budgets of Mexico and Turkey obtained through foregoing austerity policies facilitated the crisis-induced implementation of public loan guarantees and stimulus packages geared towards benefitting Mexican and Turkish capitalist classes. Second, the central banks cut interest rates dramatically. In Mexico, interest rates decreased from 8.25 to 4.5 per cent in 2009 and in Turkey from 16.75 in 2008 to 6.75 per cent in 2009. Third, fiscal spending and lower interest rates displaced the centrality of high interest rates in attracting portfolio investment and diminishing inflation. Cheap labour costs remained integral to the existing policy framework, nevertheless, in the aftermath 
of the crisis. For this reason, Mexico and Turkey found themselves in a relatively favourable context following the global crisis, at least in terms of an open financial world market channelling ample, cheap global liquidity into these countries. These measures however took different institutional shape according to the balance of forces within each nation-state.

In what follows, we illustrate how the variegated implementation of economic policy in Mexico and Turkey reflects the influence of class forces in shaping economic decisionmaking during the post-crisis period of 2010-14. Mexican state authorities followed an orthodox approach to economic policy and locked in the role of labour as an anchor of economic stability through legal and constitutional changes. This was the outcome of an increasing interest convergence among the capitalist class dominated by large corporations around the economic agenda of an authoritarian Mexican state in the context of criminalization of dissent and violence. In contrast, Turkish state authorities approached post-crisis recovery in more unconventional ways and passed the costs of financialization onto workers in a less coordinated manner. In the context of deepening violence and repression, the increasingly authoritarian Turkish state still actively mediated conflicting interests within the capitalist class, particularly between large corporations, international investors and micro, small and medium size enterprises (MSMSE), but in a more heterodox approach to neoliberal deepening. In both cases, labour has been become more firmly instituted as an anchor of post-crisis neoliberal restructuring. It is worth highlighting here, moreover, that these real world crisis and recovery experiences precede, and inform, similar best practice policies presented by the World Development Report 2014.

\section{State Policy and Financialization}

In the aftermath of crisis, fiscal surpluses, reserve accumulation, and monetary interventions in Mexico and Turkey helped preserve the value of the peso and the lira respectively, albeit unequally so. These interventions also helped to protect the exchange rate value of financial assets in each country. This was central to nonfinancial and financial firms operating in Mexico and Turkey as large national corporations became more implicated in open financial markets operations while banks in these countries increased their management operations in financial services (Muñoz Martínez 2014a; Akkemik and Özen 2014).

Authorities worked to regenerate fiscal surpluses in both countries to help guarantee the repayment of public debt, accumulate reserves, and to credibly provide public loans guarantees to large companies operating in Mexico and Turkey. Yet the source of these fiscal revenues differed. In Mexico, the fiscal balance reached an average surplus of 1.32 per cent of GDP between 2010 and 2014, excluding the payment of debt interests and investment in the publicly owned oil company PEMEX (Banxico 2014: 250). Fiscal balances were achieved through the increase of non-oil revenues, particularly the VAT and the use of oil derivatives. For instance, the VAT revenues increased from 3.4 per cent of GDP in 2009 to 3.9 in 2014 (Banxico 2014: 301). Through oil derivatives, the Ministry of Finance was able to exercise the option to sell oil at a higher price than the one offered in the spot market, particularly in the context of declining oil prices (Blas 2012). In 2015, the Ministry of Finance obtained $\$ 6.28$ billion in gains from these financial contracts (Gómez Robles 2015). In Turkey, the Treasury reported surpluses of $0.6,1.8,0.8$, and 1.0 per cent of GDP from 2010 to 2013 . The positive revenues came from the wholesale sell-off of public lands to corporate developers, savings on expected debt interest payments, interest revenues from the Unemployment Insurance Fund's capital base, and one-off revenues that included some tax arrears payments and significant privatizations (Treasury 2011-14). As austerity led to fiscal savings, the accumulation of foreign reserves increased - by 62 percent in Mexico and by 57 percent in Turkey between 2010 and 2014 (Table 1). 
Mexico and Turkey retained their international creditworthiness by facilitating the repayment of public debt and by helping to maintain the value of the currency through foreign reserve accumulation. In doing so, Mexico and Turkey exercised a core World Development Report best practice policies vis-à-vis financial risk management namely, build up both fiscal and foreign reserve buffers in the 'good' times to overcome the 'bad' times, wherein Turkey was singled out as an example (World Bank 2013, 235).

The preservation of the value of Mexico's and Turkey's currency remained the focus of monetary policy, but in different ways. In Mexico, the Central Bank, through US dollar auctions, can intervene in foreign exchange markets by using international reserves. In December 2011 for example, the central bank, through the Foreign Exchange Commission (FEC), offered daily auctions of 400 million dollars at a the minimum price of 1.02 times of the Mexican peso, as determined by the exchange rate of the preceding business day (Banxico 2011: 54). In 2012, there were three auctions worth 646 million dollars. This mechanism was triggered when the exchange rate depreciated by two per cent vis-à-vis the US dollar with respect to the previous day. The FEC suspended these auctions in 2013 and then resumed them in 2014 (IMF 2015a). This central bank intervention aimed at providing liquidity to the Mexican financial sector and at increasing the supply of US dollars to boost the value of the Mexican peso. In Turkey US dollar auctions also constituted important direct interventions aimed at protecting the currency. For example, on 10 July 2013 the Central Bank of Turkey (CBT) sold off $\$ 1.4$ billion to defend the falling Lira. Six months or so later, on 23 January, the CBT sold off $\$ 3$ billion to the same end. This conventional mechanism has been supplemented in Turkey. In late 2011 the CBT designed and implemented an unorthodox monetary intervention mechanism through the Reserve Options Mechanism (ROM) in late 2011. The ROM enables banks in Turkey to hold a given ratio of their TL reserve requirements in foreign exchange $(F X)$ and gold (Alper et al. 2013 , 2). Central Bank authorities affect the cost of using the ROM by adjusting the ratio of $\mathrm{FX} /$ gold needed to cover Lira required reserve levels on a daily basis. The intent was to stem short-term inflows, moderate domestic credit growth, and assist exchange rate and inflation volatility by encouraging banks to keep more of their own required reserves in FX (IMF 2012, 1; Aslaner Çıplak, Kara and Küçüksaraç 2015, 4). In this case, monetary policy in Mexico and Turkey demonstrated, in different ways, a WDR 2014 concern for the prudential use of foreign reserves macroprudential as part of financial risk management preparedness as well as the pro-systemic stability use of countercyclical monetary policy and foreign reserve accumulation and reserve auctioning.

Unlike rounds of neoliberal experimentation prior to the 2008-09 global financial crisis, protecting low interest rates remained central to the economic policy agenda in the aftermath of the crisis. A low interest regime, however, did not significantly affect these countries' inflation rates, which stayed at comparatively low levels (Table 1). State authorities maintained low interest levels differently. The Mexican central bank further reduced the overnight inter-bank lending rate from 4.40 per cent in 2010 to 3 per cent in 2014. Authorities pursued low rates as a means of fostering growth and development through credit (Banxico 2012: 46).

In Turkey in 2011 the Central Bank initiated the interest rate corridor (IRC) (Alper et al. 2013; Aslaner et al. 2015). The IRC is defined by the difference between the Bank's overnight borrowing and lending rates and it was conceived as part of Turkey's financial authorities' monetary toolkit to help manage exchange rate volatility through affecting short-term transactions. Consequently, interest rates in Turkey shift regularly, even chaotically, making the concrete determination of the interest rate in Turkey a complex exercise in and of itself (Candemir and Peker 2014). When first announced in 
2011, for example, the IRC was between 5 and 12.5 per cent, with authorities offering rates nearer the top-end to control credit and to cool off the economy in line with its inflation target. The average interest rate for 2011, however, ended up around six per cent (Table 1). The IRC range then fell to the 3.5 to 7.5 per cent range, with the average running around 5.5 per cent for 2012 and then 4.5 for 2013. The goal of this type of monetary intervention was to curb credit growth to prevent inflation while fostering economic growth (Reuters 2011). While unorthodox in conventional terms, the intention was to nonetheless provide of financial stability in Turkey. This strategy, however, exposed both countries to foreign capital exit and borrowers' currency mismatches that, in turn, would reinforce the apparent necessity for their state authorities to intervene given, in conventional views as in the WDR 2014, "the financial system is naturally procyclical” (World Bank 2013, 205; emphasis added).

In both cases, fiscal surpluses, reserve accumulation and monetary interventions helped to provide currency stability as well as incentives for those investors and corporations holding financial assets (see capital account in Table 1). Yet, inflationary pressures from financialization remained while a relatively strong currency jeopardized profit from exports, particularly in a context of international demand (see current account in Table 1). The contradictions resulting from these policies were therefore mediated by maintaining low labour costs while creating internal aggregate demand through consumer credit, namely financial expropriation. At the same time state financial policy aimed to reduce the exposure finance capital faces to encourage their recurrent flows into each countries.

\section{Restructuring, Labour and Financial Expropriation}

In Mexico and Turkey post-crisis, state authorities facilitated the transferring of the costs of resuming fiscal surpluses and maintaining reserve accumulation processes onto labour. In the case of Mexico, reliance on VAT for revenues targeted workers because the latter cannot claim the tax credit on the VAT that large companies operating in Mexico receive. At the same time, VAT tax returns to companies have increased significantly since the 2000s (Banxico 2014). In Turkey, the dispossession of workers from public assets through privatization was key in the generation of fiscal surpluses. In relation to reserve accumulation, both central banks have to sterilize their reserves denominated in foreign currency by issuing public bonds. As a result, state authorities have to pay the cost of the spread between the interest rates in public debt and the returns they obtain from their foreign assets through austerity and regressive taxation (See Rodrik 2006; Cho 2014).

More significantly, the new phase of low interest rates in economic policy signalled the consolidation of labour as a key mechanism to reduce inflation, directly putting downward pressure on wages, in both Mexico and Turkey. Such downward pressure is reflected in stagnant wages with hikes in food prices between 2010 and 2014 (Table 1). In Mexico, the difference between minimum wages in 2010 and 2014 was only 1.01 per cent while food prices have rose an average of 3.85 per cent in the same period (Table 1). Workers' wages decreased from 1.2 from 2003 to 2008 to -5.9 per cent from 2008 to 2013 as a share of companies' operations costs in Mexico (INEGI 2014). Indeed, the central bank has recognized that stagnant wages have facilitated the management of inflationary pressures coming from global financial volatility (Banxico, 2011: 22; 2012: 17; 2013: 255; 2014: 43). Yet in terms of labour markets, the WDR 2014 approach is to bypass wage levels stagnation and to focus instead on market access and flexibility as a means of mitigating the risks workers face $(2013,10 ; 22 ; 27-8)$

This downward pressure in Mexico also took the form of constitutional reforms in relation to labour, education, oil sector and taxation. Both the labour reform of 2012 and the transformation of the education system in 2014 promoted more flexible labour 
contracts, leading to job insecurity. For instance, the new labour law introduced new forms of contracts to ease the dismissal of workers and diminish companies' expenses in social benefits. The education reform was a labour flexibilization legislation that tied job security, promotion and wages to the assessment of teachers (Banxico 2013: 115; OECD 2015: 53). These reforms represented direct downward pressures on labour costs, consolidating the fixity of labour within Mexico's borders as an important anchor of inflation. The energy reform of 2014 opened the state owned oil and electricity sectors to private investment (OECD 2015: 24-25). The privatization of the main source of state revenues exposed funding for public spending to the fluctuations of the market, enhancing the Mexican state's self-imposed neoliberal austerity. The taxation reform eliminated corporate tax deductions related to workers' fringe benefits, further decreasing large corporations' incentives to provide these allowances to their employees. Also, authorities increased taxation on small and medium enterprises (SMEs). These SMEs are usually income supplements to precarious wages or a replacement for the lack of job opportunities. This meant that the Ministry of Finance considered SMEs in the same position as large companies in terms tax obligations without having the tax credits received by large corporations (Flores 2013). At the same time regressive taxation remained intact, particularly in relation to the VAT and corporate tax exemptions.

In Turkey from 2010 to 2014 Turkey the real minimum wage increased by about 10 per cent in PPP terms (Table 1). Minimum wages annual increases in 2013 and 2014 were 1.85 and 1.29 percent respectively while food prices rose an extraordinary 9.1 percent and 12.6 percent in the same period (Table 1). Thus, increases in the minimum wage did not have a significant impact in the purchasing power of workers. These wage rises had a widespread, popular effect in a country where employment is dominated by agricultural and micro, small, and medium-size enterprises (MSMEs) (TÜIK 2012). Authorities felt the need to respond to the concerns of MSMEs by increasing indirect taxes in 2011 (see IMF 2012a, 8). The shift to indirect taxes, as opposed to direct, labour-based taxes, structurally benefits business but are regressive from a popular class perspective. In Turkey, indirect taxes now constitute 50 per cent of tax receipts and about 13 per cent of GDP (World Bank 2014). State authorities have sought to compensate employers for post-crisis wage increases by moving forward on plans to make the workforce more flexible to employers' needs and by reducing direct payroll taxes (Duman 2014; MÜSIAD 2014).

In post-crisis Mexico and Turkey, state authorities attempted to solve the problems arising from low wages, deteriorating labour conditions and low levels of global aggregate demand by spurring domestic demand through consumer debt. Between 2010 and 2014 household outstanding loans to commercial banks increased 67 per cent in Mexico and by 103 per cent in Turkey (IMF 2015b). In the case of Mexico, promoting consumer debt-driven demand was part of major legal reforms carried out in 2012. Financial reforms aimed at facilitating more access to credit to help Mexican households compensate for losses in their purchasing power (Banxico 2014: OECD 2015). In 2009 consumer credit declined 19.1 per cent. But by 2010 it had increased by 2.6 per cent, before skyrocketing by 19.7 per cent and 15 per cent in 2011 and 2012 respectively (Banxico 2010: 32; 2011: 31; 2012: 31). Debtfare state policies and its consequences on credit availability for working crisis began in 2000 , ranging from mortgages, micro-credit, payroll credit to retail lending (Soederberg 2014: 206-212). Foreign and domestic banks in Mexico, however, benefited from the changes in financial regulations as they facilitate creditors' capacity to recover loan collateral and, by extension, reduce the banks' financial risks (Hernández 2013; OECD 2015: 22). In Turkey, too, consumer debt has increased post-crisis. Consumer loans and credit card debt exploded from 1.8 per cent in 2002 to 12 per cent in 2009 to 18.7 per cent as a percentage of GDP in 2012 (Karacimen 2014, 163). The size of the increase, however, 
was seen as constituting new substantial risks. For that reason, Turkey's Banking Regulation and Supervision Agency sought to re-regulate the credit market in ways that did not stifle credits while balancing the need to mitigate default risks. In 2013-14 consumer loan growth slowed, but still accounted for around 30 per cent of total bank loans (BAT 2014, l-10).

In more critical terms, the changes associated with wider calls for 'financial inclusion' bring with them greater legal capacity for financiers to dispossess poorer individuals and households by more forcefully protecting creditors' private property (that is, their loanable credits). To the extent that the negative side of financialization registers with IFIs like the World Bank, it is often couched in terms of legal consumer protection measures or the creation of a new financial ombudsperson to help mediate the often exploitative practices (or mounting financial risks) within consumer finance (indeed, citing Mexico as an example) (World Bank 2013, 203; Soederberg 2014: 194).

The growing use of consumer credit in both countries reflects emerging survival strategies for workers and popular classes. It also represents financial expropriation as workers take credit and pay interest on it based on the expectation of future earnings. The need for such credit is materially tied to the labour market reforms that promote cheaper labour costs and more flexible conditions, which heighten the workplace precariousness at the same time that the disciplinary elements of using personal credit for daily needs are intensified. This condition entails very real, and exploitative, class relations as banks' premise accumulation strategies around dispossessing workers of the earned income, while lobbying for stricter property rights laws to ensure repayment or repossession of goods should consumer debts be unpaid (Karicimen 2014).

In both cases, the targeting of labour as bearers of the costs of capitalist contradictions in the context of financialization has led to higher levels of poverty and inequality in both countries. In Mexico and Turkey one of every five people lived in poverty in 2014 (OECD 2014b). The share of the economy of the 20 wealthiest per cent increased from 53.8 per cent to 54.1 in Mexico and from 45.64 to 46.59 in Turkey from 2006 to 2012 (World Bank 2015). Mexican and Turkish authorities have managed to create and maintain a fiscal buffer that enables them to engage in windfall spending sprees at politically strategic moments, thus maintaining political rule, without falling into deficit and increasing debts, thus without threatening runaway inflation or financial creditworthiness imperatives. In this way neoliberal authorities have gone a long way to deepening the financial world market and ensuring its stability in their own particular corner - as mediated by the labour of workers.

\section{Economic Decision-Making and Class Power}

Both Mexican and Turkish authorities had similar policy goals in relation to currency stability, low interest rates and low inflation in the aftermath of the 2008-09 global financial crisis. Also, the outcome of transferring the costs of these policies onto labour, were comparable in both countries, particularly in relation to low wages, labour repression and inequality. Yet policy implementation took different forms: policy-making is contingent upon historically inherited forms of national regulation that involve multiple interests and socially-located actors embedded in place-specific power and class structures. The territoriality of state power and its position within the hierarchy of the world market infuse policy-making with a logic distinct from that of large globally-mobile corporations and other factions of the capitalist class. Neoliberal state officials have vested interests in promoting capitalist growth within their territory to use capital accumulation to sustain state power in the context of inter-state competition in the global economy (Harvey 2014: 157). At the same time, financial policy-making has tended towards the centralization and concentration of authority within independent, yet powerful, institutions. The conventional logic being that this decreases risks of 
mismanagement and increases professional oversight in the interests if financial stability. In Mexico in the aftermath of crisis, policy implementation followed more orthodox measures prescribed by the International Monetary Fund and legally locked in measures to anchor economic stability to the price of labour power (Lagarde 2014). In Turkey, state authorities mediated highly divergent competing interests, shaping the heterodox forms of economic state intervention. In both cases, economic measures were implemented in the context of concentration of political power around the Executive in both countries.

The orthodox economic path undertaken by Mexican state authorities hints at the dominance of a handful of corporations in the economy and the political convergence of Mexico's capitalist class around the policy agenda set by a more authoritarian state. In the case of Mexico, the crisis set a new political juncture during the presidential and Congress elections of 2012. Economic stagnation and increasing violence during the National Action Party (PAN) presidency (2000-2012) led to the triumph of the Institutional Revolutionary Party (PRI) in the 2012 presidential elections and this party's majority in Congress. In addition, the PAN presidential administration obstructed the momentum of the left-centre presidential in the 2012 presidential elections by allowing the PRI's fraudulent practices in these elections to guarantee the continuation of neoliberalism (Dresser 2012). Economic and physical insecurity and the concentration of political power around the PRI set the conditions for the implementation of reforms that further consolidated labour costs and the dispossession of households, via low wages, austerity and consumer debt, especially through constitutional reforms and legal changes, as the main mechanism to manage the uncertainty of profits. In the aftermath of the crisis, the levels of violence increased while impunity remained. The number of disappearances rose to 12500 , almost half of the total disappearances since 2006 while 14000 people were murdered only in 2015 (Redaccion AN 2015; Arturo Angel 2015). The constant threat of being killed or disappeared, whether by the state or drug cartels, incites fear, limiting the range of strategies that workers and the poor can use to bargain with both employers and the state and to protest against the deterioration of working conditions (Clercq Ortega and Sánchez Lara 2015). State security forces and organized crime units have abducted and threatened labour and human rights defenders as well as journalists (Muñoz Martinez 2014b). This climate of fear in Mexico serves as a form of social control under neoliberalism, by constraining social dissent (Muñoz Martinez 2015). Constrained social dissent alongside an increasingly insulated financial apparatus reflect neoliberal calls for depoliticization.

The aftermath of crisis in Mexico witnessed a parallel process of converging interests among financial investors, large Mexican companies, and the export sector around ensuring the low cost of labour within Mexico. The low cost of labour was not only beneficial to the Mexican and foreign exporting sector in the country but also to large Mexican corporations with national production and financial investors participating in the market of Mexican private shares and bonds. For that reason, the Association of Mexican banks, which represent the financial sector, the Business Coordinating Council and the Mexican Employers' Association, which advocate for the interests for the Mexican companies and the Executive Council of Global Enterprises, strongly supported the economic agenda of Mexico's authoritarian state (Robles Miaja 2015; González 2015; CEEG 2015). In general, most business associations, which are dominated by large Mexican and global companies, championed the post-crisis restructuring and economic reforms because they not only lowered labour costs but also opened new areas of investment to safeguard their existing investments in Mexican assets (Pallares Gómez 2015)..

In Mexico one main source of discontent among the capitalist in relation to restructuring and economic reforms was an increase in corporate taxation, particularly in the 
exporting companies, global corporations in the food industry and the service and commerce sector (Redacción 2013). Export processing industries, large food companies and the commerce and service sector disagreed with increasing taxation (Redacción 2014). Still, these interests remained supportive of the labour, education and energy reforms because the latter allowed large corporations to access cheaper credit and investment telecommunications and energy markets. And ultimately, the consensus relied on the state authorities' ability turn labour into the main mechanism to manage inflationary pressures and currency instability and provide conditions of production at low cost (KPMG 2015: 10, 13, 16, 21, 45). This shows how the political consensus around the PRI's economic agenda allowed state authorities to implement orthodox measures to deal with capitalist contradictions in the aftermath of the crisis.

In Turkey in the aftermath of crisis, policy-making was heavily influenced by the state authorities' balancing of the needs of Turkey's large corporations and the politically significant MSMEs. The ruling Justice and Development Party (AKP) assumed an increasingly autocratic approach to governing under Prime Minister, then since 2014 President, Tayyip Erdoğan. A series of elections shaped the politics of the period. Turkey faced general elections in 2011 and in 2015. These were punctured by nationwide local elections in the spring of 2014 and the first-ever Presidential election in the summer of 2014 (which went to Erdoğan). The AKP retained its majority government until the June 2015 general elections, losing its majority status held since 2002 but still earning about 40 per cent of the vote. President Erdoğan drove Turkey into snap reelections for November 2015 while the AKP-led caretaker government reignited civil war in Turkey with the Kurdish population. This was an attempt to use the politics of fear to regain Parliamentary control. Violence increased across Turkey, marked by suicide bombings and widespread insecurity, and the AKP captured over 49 per cent of the vote and a majority mandate in November. The AKP majority win opened a renewed phase of authoritarian practices. This centralization of power around the Executive relied on a careful balancing of competing economic class interests within Turkey's capitalist class. This provides insights into the way in which domestic class structures influenced the unorthodox economic measures implemented in the aftermath of the crisis in Turkey.

An economic agenda focused on maintaining a disciplined, flexible, and lower cost labour force cut across and united the class interests of three prominent capitalist groups: larger holding group 'Istanbul' capital, often smaller MSME 'Anatolian' capital; and foreign investors (cf. Hosgör 2011; IMF 2014). Both domestic capitalist groups have vested interests in low labour costs to keep input costs down, supporting their competitiveness. Yet they differ on access to credit and currency stability. This too helps explain the implementation of unorthodox monetary interventions, particularly the IRC and the ROM. For example, representatives of Anatolian capital point to the need to increase competition in Turkish labour markets, but also to increase their access to cheaper loans from the banks in Turkey (MUSIAD 2014, 19; 28-9). This is significant as retained earnings are a major source of investment financing for MSMEs, so the lower the wage bill the more capital available for investment. At the same time, the MSMEs are major exporters, and thus have an interest in anti-inflationary policies to stabilize business planning as well as competitive exchange rate and access to cheap credit. For that reason, the IRC remained in place to foster access to credit through relatively low rates. At the same time, disagreement over the IRC has come from international financial investors as well as Istanbul capital (Bogler 2015).

Istanbul capital shares an expressed interest in greater labour flexibility, which allows them to likewise adjust export production costs more smoothly according to world market conditions (Duman 2014). But Istanbul capital has a much stronger stake in maintaining access to cheap foreign finance. This in turn depends on the strength of 
the currency and profitability. The Central Bank implemented the ROM not only to guarantee demand for the TL but to also allow commercial banks to borrow additional foreign exchange to free up TL held in the Central Bank and gain from lending money domestically in liras at attractive rates (IMF 2013). In contrast to MSMEs, Istanbul capital alongside foreign investors have lobbied for an increase in interest rates to increase the profitability of their financial assets tied to the TL. Turkish state authorities act to balance the interests between the two major fractions of domestic capital, Anatolian and Istanbul capital, with a view to workers and popular classes in order to support its domesticated form of neoliberalization.

Contrary to any expectation that authoritarian neoliberalism and downward pressure on labour would lead to a virtuous cycle of growth and prosperity for all, latent contradictions remain in Mexico's and Turkey's capital accumulation strategies due to the short term composition of these capital flows as workers continue to reap few, if any, substantive benefits. Thus state policies have not made capitalist contradictions disappear but rather transferred them and intensified them in a particularly class-based fashion. In addition to increasing levels of poverty and inequality, the Ministry of Finance continues to issue public bonds, increasing the levels of public debt in the aftermath of the crisis (Table 1). In this sense, the constant threat of devaluation, the volatility of public debt markets and the cost of repayment of government bonds has increased the vulnerability of the Mexican economy. The financing needs in the country have increased to compensate for increasing imports and foreign liabilities as well as to compensate for the potential decline of foreign direct and portfolio investment (Johnson 2015). In Turkey, private debts have been on a sharp upswing since 2010 (in part enabled by austerity-driven public debt decreases) (BAT 2015, I-8). Mounting private debts have unintentionally helped to undermine the value of fixed assets held in TL terms in Turkey (despite public austerity measures to counter this).

Accounts within the political economy of finance that seek to sterilize contemporary economic realities by reading class dynamics out of global financial processes obscure the highly politicized and often violent nature of financial risk management today. This can lead to a distortion of the real costs (and benefits) of finance for development strategies promoted by IFIs and of the policies state authorities undertake to mitigate what are understood as necessary risks for developmental progress. The problematization of notions of risk and risk management promoted by IFIs such as the World Bank through the 2014 World Development Report is crucial to reveal the political nature and exploitation hidden in technical solutions to financial crisis and recurrent instability.

In the Aftermath of Crisis: Locating the World Development Report 2014 With the rise of neoliberalism and in the aftermath of crisis, we see in the cases of Mexico and Turkey that the responsibility for protecting the world market involves complex methods of labour repression within national borders in ways constitutive of the financial world market. So too does this occur at the level of contemporary IFIs. These institutions gain knowledge from national and world market processes and provide important institutional and material resources in ways that shape domestic and world financial markets. The World Development Report 2014 (WDR 2014) and in its approach to financial risk management represents a specific neoliberal synthesis of market-oriented policy knowledge and technical expertise. This section reads the WDR 2014 in light of our study of Mexico and Turkey. We argue that the WDR is not neutral representation of knowledge, but class-based and disproportionately functions in the interests of financial capital and neoliberal continuity. The WDR 2014 does so through its representation of financial risk management. Specifically, the Report mystifies and naturalises its neoliberal approach; then conceptually neutralizes it; and finally is concretely delimits the legitimate confines of policy as neoliberal. Each step accepts 
labour as a natural anchor of financial crisis management, and hence contemporary financialization.

The WDR 2014 begins by mystifying and naturalizing its presumed class-neutral approach to financial risk. The Report frames risk management as a necessary state policy tool for development (World Bank 2013, 3, 5). 'Risk' is then defined as the 'possibility of loss', posed both as a burden for state authorities but equally as indispensable for creating developmental opportunities (World Bank 2013, 4-5). 'Risk management' is thus conceived as increasing one's capacity to minimize losses and to increase the benefits of taking risks $(2014,5 ; 8)$. In this narrative, risk management is pitched as in the benefit of all, linking investors and workers together, and as necessary for preventing future developmental setbacks (World Bank 2014, 8; 62). The WDR 2014 here continues a theme established in the World Bank's 2012 inaugural Global Financial Development Report 2013: The Role of State in Finance (World Bank 2012; also see World Bank 2013, 18; 21). In both World Bank reports, the message remains that greater exposure to global financial markets is vital for development; yet, given recurrent financial market volatility, for which they foresee no end in sight, state authorities must find means of protection for markets. This should involve developing institutional forms of self-insurance and policy instruments 'that transfer resources across people over time to effectively counter financial shocks (World Bank 2013, 14). Yet contemporary crisis management demands that "resources should be provisioned for residual liabilities that the state may have to bear" (World Bank 2013, 33). How labour disproportionately absorbs the costs of risks with financial capital benefits disproportionately is left a mystery.

The WDR 2014 then conceptually neutralizes the socially unequal processes required to manage financial risk. This entails setting financial risk management on broad conceptual grounds along a continuum of preparation to coping. The Report sees the continuum as defined by the "interlinked components of risk management", which include knowledge, protection, insurance (which together constitute preparation), followed by coping $(2013,63)$. Knowledge acquisition and usage is framed as necessary for understanding the nature and likelihood of financial risks so as to reduce uncertainty and better inform actions $(2013,64)$. Public authorities should have an important in reducing financial uncertainty by facilitating access to and dissemination of reliable data on risk, but also by offering regulatory stability and predictability (2013, 65). Protection involves building capacity to reduce negative outcomes and enhance positive ones $(2013,65)$. The public and state are recognized as the likely providers of protection against systemic risks such as economic crises $(2013,67)$. Insurance is meant to "cushion the blow" of shocks $(2013,67)$. In the Report, this means having instruments capable of transferring resources between "good and bad times" (that is, displacement in time for example through savings, formal insurance contracts, loans, credit lines, and hedging instruments) and to those "especially in need in bad times" (for example, social safety nets, community support, or other risk-pooling mechanisms) $(2013,67)$. As with protection, the Report suggests insurance can be provided by individual, purchased from the market, or obtained from the public sphere $(2013,67)$. In terms of extreme shocks, like financial crises, communities and states could provide the support against shocks not covered by market insurance $(2013,67)$.

The WDR 2014 sees these three components as constituting preparation, that is, before the fact risk management $(2013,68)$. Coping, however, entails risk management actions taken after a risk (or an opportunity, the Report qualifies) has emerged (2013, 68). This involves ensuring that the regulatory authorities' knowledge base takes account of the new conditions and is used to implement necessary and available resources properly $(2013,69-70)$. Coping actions can range from minimal interventions that support a quick recovery to more extensive interventions required by larger shocks 
$(2013,70)$. As an example of the latter, extensive type of intervention, the Report cites how the "good macroeconomic management allowed a number of developing countries to recover relatively quickly from the 2008-09 global financial crisis" $(2013,70)$.

The WDR 2014 also delimits the range of legitimate financial policies derivable from the interlinked components of risk management. The Report does this by rendering a variety of market supporting practices actionable through a neoclassical economic and neoliberal interpretive lens and by representing this combined knowledge in ways that can be internalized by national authorities $(2013,217 ; 244)$. Knowledge production policies become functional to financial development, as national priorities should include better and system wide data collection and public dissemination; improved quality; leading to monetary transparency and disclosure of financial risks - in the interests of financial deepening. Protection takes an uncompromising conventional turn as priorities should include establishing legal frameworks; financial and central bank institutional independence; corporate governance standards; consumer protection and government transfer plans; financial deepening; stronger macroprudential and fiscal frameworks and institutions, leading to inflation targeting and flexible exchange rate regimes, and crisis preparedness plans. Insurance priorities add in consumer protection and mandatory insurance and macroprudential capital buffers but also countercyclical monetary policy and foreign reserve accumulation. In terms of coping after the risk appears, policy priorities include contract enforcement (that is, private property rights); failing bank resolution; emergency liquidity and bad debt resolution; preserved access to credit and blanket deposit guarantees; consumer protection; lending guarantees; support from IFIs leading to contingent credit lines. There is no mention of systemic re-evaluation as the current financialized world market is accepted as given, natural, and necessary. National best practices are naturally needed to protect a system that is both necessary and desirable, from the perspective of financial development and financial capital.

The naturalized approach to financial risk and the conceptual generality at which the WDR 2014 frames financial risk management lends itself to broad-based consensus formation and uptake into national policy making processes. The concrete policy recommendations narrow the range of interpretation into a definitively market-oriented and neoliberal trajectory. The strategy of naturalization and conceptual generality obscure the underlying and exploitative social power and class relations that emerge in the actual concrete practices of financial risk management. As a result, serious contradictions emerge at a systemic level and with the role of the public sector. At this scale the Report's narrative sees the likely provider being the state, which is the otherwise defined as inherently 'corrupt' and 'inefficient' (also see World Bank 2012). Moreover, while ideally open to democratic debate the Report has little to no time for actual democracy as the clearly demarcated confines of policy options reproduce the existing capitalist order. Indeed, policy anchors such as financial institutional independence actively militate against democratic accountability. Therein, the financial best practices ensure the least possible be done by public authorities to appease workers and the poor, while promoting market-based financial mechanisms that encourage broad-based financial inclusion processes that intensify financialization (that is, the dispossession of the poor and workers). The Report, in its approach to financial risk management in the aftermath of crisis, thus reflects continuity in the post-1980s neoliberal contention that all developmental problems can be best resolved by more exposure to market processes and competition. It represents an innovation insofar as the role of the state is more explicitly acknowledged in preserving the financial system by building capacity to manage financial risks, including socializing them, should the crisis be severe enough that market mechanisms are insufficient. This, however, needs 
to be understood in its class-based foundations that privilege the needs of capital accumulation over the social reproduction aspirations of the majority of society as analysed in the Mexican and Turkish cases.

\section{Conclusion: An Alternative Agenda in the Aftermath of Crisis}

Just as forms of labour repression characterize Mexican and Turkish authorities' responses in the aftermath of crisis, so too the World Bank's response in its framing of financial risk management. In Mexico and Turkey, the intensification of workers' repression can be seen through concrete post-crisis initiatives in economic decisionmaking, economic restructuring, and financialization. The World Development Report 2014 then mystifies neoliberal policies that depend on labour to stabilize global financial risks while concretely legitimizing the specific financial policies needed to reproduce the current financial architecture.

The aftermath of crisis has neither led to a spontaneous resurgence of organized labour against neoliberal intensification nor to utter collapse. In Mexico, major labour unions like the CTM (Confederation of Mexican Workers) remain closely aligned to the government, and especially the ruling PRI. This facilitates the anchoring of labour costs to inflation and mitigates collective responses to the deepening of financialization. The continued precariousness of work and forced return of undocumented workers from the crisis-affected US has worsened matters are unionization levels continue to fall. Yet more independent and representative worker organizations have emerged and resisted authoritarian neoliberalism. The Tri-National Solidarity Alliance formed in 2010 drawing together progressive worker organizations across Mexico, the US, and Canada. In Mexico, more independent unions like the Frente Autentico de Trabajo and Union Nacional de Trabajadores are involved along side militant mine and metal workers, electricians, and telephone technicians. In 2013, the National Coordinating Committee of the Mexican Teachers' Union led one the largest strikes in Mexico's recent history. In 2015 farm workers in the north led an unprecedented blockage of fresh produce deliveries and maquiladora workers challenged global giants like Foxconn. The common denominators included aspirations for better wages, working conditions, and more effective representation, as well as being repressed by the military and police in Mexico.

Turkey illustrates a similar tendency, though the specifics differ. Conservative labour unions (such as Hak-Iş and Memur-Sen) have been drawn much closer to the ruling AKP, becoming privileged actors in official negotiations. Less government-friendly but worker-oriented unions like DISK, KESK, and Turk-Iş are systematically discriminated against in the collective bargaining process. Like Mexico, unionization in general is on a downward trend, yet most newly unionized workers are channelled towards the progovernment organizations that have accepted minimal minimum wage increases and not challenged the AKP on its continued refusal to allow civil servants the legal right to strike. Nevertheless, the aftermath of crisis has encouraged unions like DISK and KESK into more open dialogues, often with the progressive HDP (People's Democratic Party). Popular mobilizations, too, have emerged. The TEKEL resistance in late 2009 and early 2010 saw thousands of workers push back against job losses driven by the privatization of the state-owned tobacco and alcohol enterprise. The 2013 Gezi Park resistance was a massive popular movement against the commodification of public space in central Istanbul. More recently in 2015, metal workers took on Renault and Bosch. The TEKEL and Gezi Park movements were brutally crushed by police forces, while the metal workers' strike also suffered from the AKP deeming it a matter of 'national security', and hence forcing them into a pro-government mediating council. As in Mexico, the aspirations of workers for better wages and conditions confront neoliberal governments' power to suppress labour in the interests of capitalist stability 
and global capital accumulation imperatives with little or no concern for democratic processes.

Practically and methodologically, then, our analysis stresses that it is important not to perceive the national and international scales as separate but as interlinked within the totality of capitalist social relations. The processes of capitalist reproduction within national borders are constitutive of the capitalist world market, which in turn impacts back upon the national scale (von Braunmühl 1978). In this sense one can understand the enduring importance of national financial institutions, like central banks, that function in tandem with IFIs, like the World Bank - both of which emerged spontaneously within the historical development modern global capitalism (Itoh and Lapavitsas 1999). It follows from our perspective that contemporary economic policy making occurs in a context of reflexive, but unequal, interactions between nation states and IFIs, as co-constituted, contested, and complex material and discursive processes (cf. Taylor 2012; Andersson 2016). It also follows that when labour repression becomes an anchor of domestic economic management and capitalist stability imperatives that this also be reflected in and reproduced by otherwise neoliberal IFIs. Given the commonalities found between Mexico and Turkey (all be they variegated) and the WDR 2014, this is what has happened in the aftermath of the 2008-09 global crisis. Rather than project and undertake any fundamental reform to national or global finance, advocates of financialization have more firmly linked the fate of financial capitalism to the repression of labour. The mechanisms in place and advocated for disproportionately disadvantage and exploit the poor and working classes to the benefit of capital, especially finance. This is one clue as to why, despite the global crisis being the most costly in human history and despite bringing the financial world market to the precipice of collapse, there have been no fundamental changes to the functioning of world financial markets. There is a real need to privilege a new stream of finance and development research premised on the needs of the poor and labouring workers geared towards alternative policies that are viable, desirable, and achievable. Such policy work is likely to, and indeed should, be premised on disproportionately disadvantaging the needs of financial capital in the interests of popular classes' aspirations and the democratization of finance for development. 
Table 1

\begin{tabular}{|c|c|c|c|c|c|}
\hline Indicators & 2010 & 2011 & 2012 & 2013 & 2014 \\
\hline \multicolumn{6}{|l|}{$\begin{array}{l}\text { GDP (annual } \\
\text { variation) }\end{array}$} \\
\hline Mexico & 5.1 & 4 & 4 & 1.4 & 2.1 \\
\hline Turkey & 9.2 & 8.8 & 2.1 & 4.0 & 3.3 \\
\hline \multicolumn{6}{|l|}{$\begin{array}{l}\text { Exchange rate } \\
\text { (per US dollar) }\end{array}$} \\
\hline Mexico & 12.63 & 12.42 & 13.16 & 12.77 & 13.29 \\
\hline Turkey & 1.54 & 1.89 & 1.78 & 2.13 & 2.32 \\
\hline \multicolumn{6}{|l|}{$\begin{array}{l}\text { Capital account } \\
\text { (\% of the GDP) }\end{array}$} \\
\hline Mexico & 4.6 & 4.5 & 4.3 & 5.2 & 4.4 \\
\hline $\begin{array}{l}\text { Turkey } \\
\text { (capital and } \\
\text { financial } \\
\text { account) }\end{array}$ & 7.8 & 8.3 & 8.7 & 8.8 & 5.2 (proj) \\
\hline \multicolumn{6}{|l|}{$\begin{array}{l}\text { Current account } \\
\text { (\% of GDP) }\end{array}$} \\
\hline Mexico & -0.5 & -1.1 & -1.3 & -2.4 & -2.1 \\
\hline Turkey & -6.2 & -9.6 & -6.1 & -7.9 & -6.4 \\
\hline \multicolumn{6}{|l|}{$\begin{array}{l}\text { Gross } \\
\text { International } \\
\text { reserves (billions } \\
\text { of US dollars) }\end{array}$} \\
\hline Mexico & 120.6 & 149.2 & 167.1 & 180.2 & 195.7 \\
\hline Turkey & 86.1 & 88.4 & 119.4 & 130.3 & $\begin{array}{l}135.3 \\
\text { (proj) }\end{array}$ \\
\hline \multicolumn{6}{|l|}{ Interest rates } \\
\hline Mexico & 4.40 & 4.24 & 4.24 & 3.75 & 3 \\
\hline $\begin{array}{l}\text { Turkey } \\
\text { (one week repo } \\
\text { near average) }\end{array}$ & c.7.0 & c. 6.0 & c.5.5 & C.4.5 & c.9.0 \\
\hline \multicolumn{6}{|l|}{$\begin{array}{l}\text { Public debt (\% } \\
\text { GDP) }\end{array}$} \\
\hline Mexico & 27.1 & 28.2 & 30.6 & 32.6 & 34.45 \\
\hline
\end{tabular}




\begin{tabular}{|l|l|l|l|l|l|}
\hline Turkey & 42.3 & 39.1 & 36.2 & 36.2 & $\begin{array}{l}33.7 \\
\text { (proj) }\end{array}$ \\
\hline $\begin{array}{l}\text { Real Minimum } \\
\text { wages (In 2014 } \\
\text { constant prices } \\
\text { at 2014 USD } \\
\text { PPPs)* }\end{array}$ & & & & & \\
\hline Mexico & 2101 & 2115 & 2119 & 2128 & 2125 \\
\hline Turkey & 10115 & 10419 & 10701 & 10898 & 11038 \\
\hline Inflation & & & & & \\
\hline Mexico & 4.4 & 3.82 & 3.57 & 3.8 & 4.01 \\
\hline Turkey (CPI) & 6.4 & 6.8 & 8.1 & 6.6 & 8.1 \\
\hline $\begin{array}{l}\text { Inflation (Food } \\
\text { prices) }\end{array}$ & & & & & \\
\hline Mexico & 5.1 & 6.02 & 7.2 & 5.3 & 4.8 \\
\hline Turkey & -- & -- & -- & 9.1 & 12.6 \\
\hline
\end{tabular}

Source: Banxico Database, BAT 2014; BAT 2015; IMF 2014, OECD Main Economic Indicators 2015, OECD 2014, IMF 2014. 


\section{References}

Alper, K., Kara, H. and Yorukoglu, M. (2013). Reserve Options Mechanism. Central Bank Review, 13: 1-14.

Akkemik, K.A. and Özen, Ş. (2014) Macroeconomic and institutional determinants of financialisation of non-financial firms: Case study of Turkey, Socio-Economic Review, 12:1, 71-98.

Andersson, E. (2016) Monies that Matter, on the Discursive Power of the Bank for International Settlements, Globalizations, 13:2, 203-216.

Aslaner, O., Çıplak, O., Kara, H., and Küçüksaraç, D. (2015). Reserve Options

Mechanism: Does it Work as an Automatic Stabilizer? Central Bank Review, (15), 1-18.

Banxico (2011 to 2015). Compilación de Informes Trimestrales, Mexico City.

BAT (2014 and 2015). Banks in Turkey. Banks Association of Turkey, Istanbul.

Blas, J. (2012). Mexico hedges against oil price slide. Financial Times, 25 Septiembre.

Brenner N, Peck J. and Theodore N. (2010). Variegated Neoliberalization:

Geographies, Modalities, Pathways. Global Networks 10, 182-222.

Byan, D. (1995), The Chase Across the Globe: International Accumulation and Contradictions for Nation States, Boulder: Westview Press.

Bryan, D., Rafferty, M., \& Jefferis, C. (2015). Risk and Value: Finance, Labor, and Production. The South Atlantic Quarterly, 114, 2, 307-330.

Bogler, D. 2015. Turkey: no longer bashing Basci, Financial Times, 10 June.

Candemir, Y. and Peker, E. (2014). “Turkey's Interest Rates 101: Dissecting Mr. Basci's Benchmarks", 23 January 2014, Wall Street Journal, 23 January, retrieved from http://blogs.wsj.com/moneybeat/2014/01/23/turkeys-interest-rates-101-dissecting-mrbascis-benchmarks/

Cho, Y. (2014). Making the Poor Pay for the Rich: Capital Account Liberalization and Reserve Accumulation in the Developing World. Globalizations, (11)6, 809-25.

Cizre-Sakallıoğlu, U. and Yeldan, E. (2000). Politics, Society and Financial Liberalization: Turkey in the 1990s. Development and Change, 31, 481-508.

Clercq Ortega, J.A. and Sánchez Lara, G. (2015) Indice Global de Impunidad. Puebla: Fundación Universidad de las Américas.

Cleaver, H. (2000). Reading Capital Politically, Leeds: Antitheses.

CEEG (2015). El Consejo Ejecutivo de Empresas Globales cambia de presidente durante su Asamblea Anual 2015, 26 August. 
De Brunhoff, S. (1978). The state, capital and economic policy. London: Pluto Press. Dresser, D. (2012). 'Va pa' tras' Periodico Reforma, 20 March. Retrieved from http://www.reforma.com/aplicaciones/editoriales/editorial.aspx?id=23413

Duman, A. (2014). Labour Market Institutions, Policies, and Performance: Flexibility and Security in Turkey. TUSIAD-EAF: Istanbul.

Flores, L (2013). Reforma hacendaria, riesgo para Pymes. CNN Expansión. 23

November. Retrieved from http://www.cnnexpansion.com/economia/2013/11/22/tipssobre-la-reforma-fiscal

Garrido C. (2005). Desarrollo Económico y Procesos de Financiamiento en México: Mexico City.

Gómez Robles, P. (2015). Gobierno recibe US6,284 millones por coberturas. El Economista. 9 December. Retrieved from http://eleconomista.com.mx/finanzaspublicas/2015/12/09/gobierno-recibe-us6284-millones-coberturas

González, L. (2015) CCE urge consolidar reformas estructurales. El Economista. 3 August. Retrieved from http://eleconomista.com.mx/industrias/2015/08/03/cce-urgeconsolidar-reformas-estructurales

Harvey, D. (1999). The Limits to Capital, London: Verso.

Harvey, D. (2005). The New Imperialism. Oxford; New York: Oxford University Press.

Harvey, D. (2010). The Enigma Of Capital and the Crisis This Time. Paper prepared for the American Sociological Association Meetings, Atlanta, 16 August. Retrieved from http://davidharvey.org/2010/08/the-enigma-of-capital-and-the-crisis-this-time/

Harvey, D. 2014. Seventeen Contradictions and the End of Capitalism, Oxford: Oxford University Press.

Hosgör, E. (2011). Islamic Capital/Anatolian Tigers: Past and Present. Middle Eastern Studies, (47)2, 343-60.

Holzer B. and Y. Milo 2005. From risks to Second-order dangers in Financial Markets: Unintended consequences of Risk Management Systems," New Political Economy 10:2, pp. 223-245.

IMF. (2012). Turkey: 2011 Article IV Consultation, IMF Country Report No. 12/16. IMF, Washington, D.C.

IMF. (2013). Turkey: 2013 Article IV Consultation, IMF Country Report No. 13/363. IMF, Washington, D.C.

IMF. (2014). Turkey: 2014 Article IV Consultation, IMF Country Report No. 14/329, IMF, Washington, D.C.

IMF (2015a). Mexico: 2015 Article IV Consultation,_Country Report No. 15/313, IMF, Washington, D.C.

IMF. (2015b). Household Outstanding loans to Commercial Banks. National Currency. IMF eLibrary Data. Retrieved from http://data.imf.org/?sk=beadea8c-42be-472e-86909af03ffc23d1\&sld=1390030109571.

INEGI. (2014), Censos Económicos 2014. Resultados Definitivos. Aguascalientes 
Itoh, Makoto and Costas Lapavitsas (1999). Political Economy of Money and Finance, New York: St. Martin's Press.

Jessop, B. (1999). The Strategic Selectivity of the State: Reflections on a Themes of Poulantzas. Journal of the Hellenic Diaspora 25 (1-2), 1-37.

Johnson, L. (2013) Catastrophe Bonds and Financial Risk: Securing Capital and Rule through Contingency. Geoforum, 45, 30-40.

Johnson, S. (2015). Mexico and Colombia join 'fragile five' emerging markets. Financial Times, 12 August.

Karacimen, E. (2014). Financialization in Turkey: The Case of Consumer Debt. Journal of Balkan and Near Eastern Studies, 16(2), 161-80.

Kessler, O. (2007). Performativity of Risk and the Boundaries of Economic Sociology. KPMG (2015). Perspectivas de Alta Dirección en México 2015. KPMG: Mexico City.

Lagarde, C. (2014). Dare to Dream. Structural Reforms in Mexico. Remarks by Managing Director of International Monetary Fund, Mexico City, 25 June.

Lapavitsas, C. (2009). Financialised Capitalism: Crisis and Financial Expropriation. Historical Materialism 17, 114-148.

Lapavitsas, C. (2011). Theorizing Financialization. Work, Employment and Society, 25 (4), 611-626.

Lapavitsas, C. (2013). The Financialization of Capitalism: Profiting without Producing. City, 17 (6), 792-805.

Marazzi, C. (2010). The violence of financial capitalism. Los Angeles, CA, Semiotext(e).

Martin, R. (2015). Money after Decolonization. The South Atlantic Quarterly, 114, 2 , 377-394.

Marx, K. (1973). Grundrisse. Foundations of the critique of political economy. New York: Random House.

Marx, K. (1975). Early Writings. London: Penguin Books.

McDonald, D. and G. Ruiter (eds). (2012). Alternatives to Privatization: Public Options for Essential Services in the Global South, Cape Town, South Africa: HSRC Press.

Muñoz Martínez, H. (2014a) Crisis, Class and the 'Fixing' of Capitalism in Mexico. In Yildiz Atasoy (ed.) Global Economic Crisis and the Politics of Diversity, London and New York: Palgrave MacMillan, pp. 228-258.

Muñoz Martinez, H. (2014b) Criminal Violence and Social Control, North American Congress for Latin America, Spring, pp. 35-6.

Muñoz Martínez, H. (2015) The politics of scale, place, and mobility in the Mexican peace movement, 2006-2012, Canadian Journal of Latin American and Caribbean Studies, 40 (2), 157-175.

Muñoz Martínez, H. and Marois, T. (2014). Capital Fixity and Mobility in Response to the 2008-09 Crisis: Variegated Neoliberalism in Mexico and Turkey. Environment and Planning D: Society and Space, 32, 1102-19. 
MÜSIAD (2014). Türkiye Ekonomisi Raporu 2014, MÜSIAD: Istanbul.

OECD (2014). Society at a Glance 2014: OECD Social Indicators, OECD Retrieved from http://dx.doi.org/10.1787/soc_glance-2014-en Retrieved: November 2015.

OECD (2015). OECD Economic Surveys: Mexico, Paris; OECD.

Pallares Gómez, M.A. (2015). Banca prevee Mover grandes capitales. El Universal, 27 October. Retrieved from

http://www.eluniversal.com.mx/articulo/cartera/finanzas/2015/10/27/banca-prevemover-grandes-capitales-para-2016

Peck, J. (2004). "Geography and Public Policy: Constructions of Neoliberalism." Progress in Human Geography 28, (3), 392-405.

Peck, J., N. Theodore, and N. Brenner (2012). Neoliberalism Resurgent? Market Rule after the Great Recession, The South Atlantic Quarterly, 111 (2), 265-88.

Poulantzas, N. (1974). Classes in Contemporary Capitalism, London: New Left Books.

Pradella, L. and Marois, T. (eds.) (2015) Polarizing Development: Alternatives to Neoliberalism and the Crisis, London: Pluto Press.

Rathbone, JP and Thompson, A. (2013). México, con nueva ola de reformas. Revista Expansión. 14 March. Retrieved from

http://www.cnnexpansion.com/opinion/2013/03/13/reforma-a-telecomunicaciones-unreto

Redacción. (2013). "Rechazo a la Reforma Fiscal en Ocho Estampas," El Economista, 1 Octubre. Retrieved from http://eleconomista.com.mx/sistemafinanciero/2013/10/01/rechazo-reforma-ocho-estampas

Redacción. (2014). Ventas de activos impulsan acciones de América Móvil. El Economista. 9 July. Retrieved from http://eleconomista.com.mx/mercadosestadisticas/2014/07/09/acciones-amx-trepan-445-tras-venta-activos

Reuters. 2011. Turkey's interest rate corridor policy questioned. Reuters, 1 December. Retrieved from http://www.reuters.com/article/turkey-moodysidUSL5E7N10QL20111201

Roberts, A. (2013). Financing Social Reproduction: The Gendered Relations of Debt and Mortgage Finance in Twenty-first-century America, New Political Economy, 18 (1), 21-42.

Robles Miaja, L. (2015) La Banca Preparada Ante una Gran Oportunidad de Desarrollo, Remarks by the President of the Association of Mexican Banks, Acapulco, 20 March.

Rodrik, D. (2006). The Social Costs of Foreign Exchange Reserves. International Economic Journal, (20)3, 253-66.

Saad-Filho, A., and Johnston, D. (2005). Introduction. In Saad-Filho, A., and Johnston, D. (eds.) Neoliberalism: A Critical Reader. London, Pluto Press.

Secretaria de Hacienda (2014). Informe Trimestral. Estados Unidos Mexicanos, Presidencia de la República. Mexico City, Mexico. 
Soederberg, S. (2014). Debtfare States and the Poverty Industry: Money, Discipline, and the Surplus Population, Abingdon: Routledge.

Taylor, M. (2012). The International Financial Institutions, Introduction to International Development, $2^{\text {nd }}$ Ed., ed. by Paul A. Haslam, J. Schafer, and P. Beaudet, Oxford University Press: Oxford.

Treasury (2011 to 2015). Public Debt Management Report. Republic of Turkey, Prime Ministry, Undersecretariat of the Treasury. Ankara, Turkey.

TÜiK, News Bulletin 2012, no 13146.

UNCTAD (2011). Trade and Development Report 2011. Geneva, United Nations Conference on Trade and Development.

UNCTAD. (2013). Trade and Development Report. UN: Geneva.

von Braunmühl, Claudia (1978). On the Analysis of the Bourgeois Nation State within the World Market Context. An Attempt to Develop a Methodological and Theoretical Approach, State and Capital: A Marxist Debate, eds. by John Holloway and Sol Picciotto, London: Edward Arnold.

World Bank (2013). World Development Report 2014: Risk and Opportunity: Managing Risk for Development. Washington, DC: The World Bank.

World Bank (2014). Focus Note on Tax Policy and Sustainable Growth. Washington, DC: The World Bank. 